\title{
COMMON FISH SPECIES IN POLYCULTURE WITH CARP AS CYPRINID HERPES VIRUS 3 CARRIERS
}

\author{
RADOSAVLJEVIĆ V*, JEREMIĆ SVETLANA*, ĆIRKOVIĆ M**, LAKO B**, MILIĆEVIĆ VESNA*, \\ POTKONJAK $A^{\star *}$ and NIKOLIN V*** \\ *University of Belgrade, The Institute of Veterinary Medicine of Serbia, Belgrade, Serbia \\ **Faculty of Agriculture, Novi Sad, Serbia \\ ***Humboldt Universität, ZIBI Graduate School, FU Berlin, Berlin
}

(Received 4th July 2012)

Cohabitation studies with common carp were conducted to determine whether the Cyprinid Herpes Virus 3 can infect and establish a productive infection in fish species that according to available data, are not susceptible to this virus. In order to examine if other fish species can contribute to further spreading of the virus, goldfish, silver carp, grass carp, prussian carp and tench were exposed to CyHV-3 through cohabitation with infected carp without clinical symptoms. After this period they cohabitated with naive carp for two weeks and were examined for CyHV-3 by PCR. Our results showed that CyHV-3 was present in the organs of these fish species and also in organs of naive carp after two weeks in cohabitation, suggesting that CyHV-3 may cause latent infection, and also that has a potential to infect a broader host range than it was believed before. Our study adds on better understanding of CyHV-3 transmission not just in its primary host, but also suggests the importance of common fish species in polyculture with carp in the epidemiology of CyHV-3.

Key words: carp polyculture, common carp, CyHV-3, koi herpes virus, KHV

\section{INTRODUCTION}

The disease of koi (Cyprinus carpio koi) and common carp (Cyprinus carpio carpio), caused by koi herpesvirus (KHV) has been observed since 1998 in many fish farms worldwide, causing mass mortality and significant financial losses. Herpes-like virus designated koi herpesvirus (KHV, CyHV-3) has been isolated from koi and comon carp during outbreaks of the disease. The first occurence of the disease with massive mortality has been reported in 1998 in Israel and USA, and since then, several countries have experienced outbreaks of the disease, including USA, South Africa, Japan, Israel and many European countries (Bretzinger et al., 1999; Hedrick et al., 2000; Neukirch and Kunz 2001; Perelberg et al., 2003; Chien et al., 2004; Sano et al., 2004; Tu et al., 2004). An important 
feature of herpesviruses is their ability to persist in their hosts, including those with natural or vaccine-induced immunity (Kucuktas and Brady, 1999). The virus remains dormant and inactive over a long period of time, but can be reactivated and become pathogenic and cause clinical symptoms and even death.

The host range and susceptibility of CyHV-3 is still not fully understood. Typical CyHV-3 clinical signs were described only in carp and koi carp. However, several lines of carp and their hybrids (eg., Dor x Našice) have proved to be less susceptible to disease than others (Shapira et al., 2005). In addition, it was described that hybrids of golden carp and carp are partially resistant to CyHV-3 (Hedrick et al., 2006). Since the discovery of CyHV-3 infected fish in rivers and lakes in Japan (Haramoto et al., 2007; Ishioka et al., 2005), UK and USA (Grimmett et al., 2006), it has become very important to clarify the role of other fish species, cohabiting with common carp in the maintainance and trasmission of CyHV-3.

\section{MATERIAL AND METHODS}

Viruses and cells

For all tests we used KHV-I isolated from a koi carp by Hedrick et al. (2000), generously provided by Dr SM Bergmann (Friedrich Loeffler Institute, Germany). The virus was propagated in CCB (Common carp brain) cell line, created by Neukirch et al. (1999), generously provided by Dr Olga Haenen (Central Veterinary Institute of Wageningen, The Netherlands). Cells were grown in minimal essential medium (MEM) with Earl salts and L-glutamine (Sigma), 10\% fetal bovine serum (Gibco), $79.6 \mathrm{mg} / \mathrm{L}$ non-essential amino acids (PAA), $200000 \mathrm{U} / \mathrm{L}$ penicillin and $200 \mathrm{mg} / \mathrm{L}$ streptomycin (PAA), incubated at $20^{\circ} \mathrm{C}$.

\section{Animal experiments}

Fishes used in the experiment were obtained from a closed-system in the Center for Fishery and Applied Hydrobiology "Radmilovac" in Belgrade, with no history of KHV infection. The average weight of common carp (Cyprinus carpio), grass carp (Ctenopharyngeon idella), tench (Tinca tinca), goldfish (Carassius auratus), prussian carp (Carassius auratus gibelio) and silver carp (Hypophthalmichthys molitrix) was approximately $30 \mathrm{~g}$.

In order to create an asymptomatic carrier state, the protocol described by Ronen et al. (2003) was used. In brief, 10 common carp were placed in the same tank with CyHV-3-infected koi carp showing symptoms of infection and kept at $23^{\circ} \mathrm{C}$ for 5 days, and thereon they were transferred to a new tank with a water temperature of $30^{\circ} \mathrm{C}$ and kept for 30 days. The surviving fish were kept at $23^{\circ} \mathrm{C}$ for 30 days, and used in the experiment three months after the initial cohabitation with sick fish. In order to examine if other fish species can contribute to further spreading of the virus, goldfish, silver carp, grass carp, prussian carp and tench were exposed to CyHV-3 through cohabitation with the asymptomatic carrier for a 14 and 21 day period. After this period they cohabitated with naive carp for two weeks and were examined for CyHV-3 by PCR. 
Acta Veterinaria (Beograd), Vol. 62, No. 5-6, 675-681, 2012.

\section{Co-habitation procedure}

Fifteen tench were in cohabitation with virus carriers for five days. After that period, they were transferred to another tank. On the 14th and 21th day after initial contact with the virus carrier, five tench fishes were euthanized and tested for CyHV-3. Fourteen and 21 days after initial contact with the carrier, five tenches were transferred to a new tank with five naive carp fishes, where they were in cohabitation for two weeks. After two weeks of cohabitation, tenches and carps were euthanized, the organs were sampled and tested for presence of CyHV-3. Before the experiment, and at the end, five tenches that were not exposed to the virus were euthanized and tested.

This procedure has been applied for testing of other fish species in experiment.

DNA extraction and PCR amplification

Portions (approximately $0.1 \mathrm{~g}$ ) of the gill, kidney and spleen were sampled from individual fish and DNA was extracted using a DNeasy Qiagen kit, following the tissue extraction protocol (Qiagen).

The detection of KHV DNA from fish tissues was done using the oligonucleotide primer set TKf (5'-GGGTTACCTGTACGAG-3') and TKr 5'CACCCAGTAGATTATGC-3') published in Bercovier et al. (2005), and the size of the amplified fragments was $409 \mathrm{bp}$. The Eppendorf Thermal Cycler was used for amplification using 1 cycle at $94^{\circ} \mathrm{C}$ for 5 min followed by 40 cycles of 1 min at $95^{\circ} \mathrm{C}, 1 \mathrm{~min}$ at $55^{\circ} \mathrm{C}$, and $1 \mathrm{~min}$ at $72^{\circ} \mathrm{C}$, followed by a final extension step of 10 minutes at $72^{\circ} \mathrm{C}$. The inner pair of primers Intfw (5'-CGTCTGGAGGAATACGACG3') and Intrev (5'-ACCGTACAGCTCGTACTGG-3') were used for nested PCR, and the size of the amplified fragments was $348 \mathrm{bp}$. The Eppendorf Thermal Cycler was used for amplification using 1 cycle of $94^{\circ} \mathrm{C}$ for 5 min followed by 40 cycles of $1 \mathrm{~min}$ at $95^{\circ} \mathrm{C}, 1 \mathrm{~min}$ at $55^{\circ} \mathrm{C}$, and $1 \mathrm{~min}$ at $72^{\circ} \mathrm{C}$, followed by a final extension step of 10 minutes at $72^{\circ} \mathrm{C}$.

The PCR products were detected in $2 \%$ ethidium bromide stained agarose gel at $60 \mathrm{~V}$ for $30 \mathrm{~min}$ and visualized under UV light.

\section{RESULTS}

Koi herpesvirus DNA was detected in three of 15 tench exposed to the virus. DNA was detected in one tench collected 14 days after the initial contact with carp virus carriers and in two tench fishes which cohabited from 14. to 28. day with five naive carp, of which in two carp the presence of CyHV-3 genome was detected (Figure 1). There were no clinical symptoms of the disease during the experiment, or any mortality.

In four of 15 goldfish in cohabitation with infected carp were detected parts of the CyHV-3 genome. DNA was detected in two goldfish sampled 14 days after the initial contact with carp virus carriers, in one goldfish which cohabited from 14. to 28. day with five carp, of which in one carp the presence of CyHV-3 DNA was detected, and in one goldfish which cohabited from $21^{\text {st }}$ to $36^{\text {th }}$ day with five carp, of which in one carp the presence of CyHV-3 DNA was detected. Other carp and 
goldfish fishes did not show any symptoms of disease and they were CyHV-3 PCR negative.

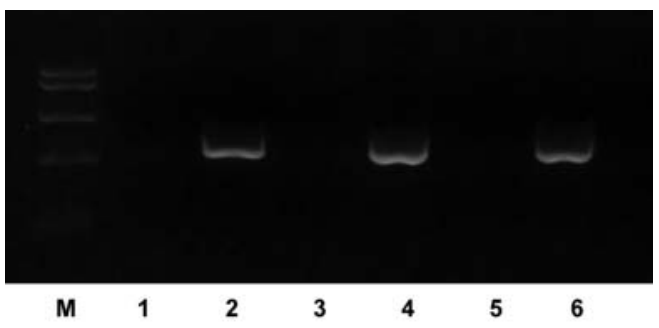

Figure 1. Agarose gel electrophoresis of PCR amplified 348 bp fragments of KHV DNA obtained from organ pools of carps. Lane 1 - negative control, lane 2 - positive control, lanes 3 and 5 - negative result, Lanes 4 and 6 - positive result, M - marker (100 bp DNA ladder)

Koi herpesvirus DNA was detected in two of 15 prussian carp that were exposed to the virus, in one prussian carp sampled 14 days after the initial contact with carp virus carrier, and in one prussian carp, which cohabited from 14. to 28. day with five carp, of which in one carp CyHV-3 DNA was detected. Other carp and prussian carp did not show any symptoms of disease and they were CyHV-3 PCR negative.

Part of the CyHV-3 genome was detected in one of 15 silver carp in cohabitation with the virus carrier. This silver carp cohabited from day 14 to day 28 with five naive carp, of which in one carp CyHV-3 DNA was detected. Other common carp and silver carp did not show any symptoms of disease and they were CyHV-3 PCR negative.

Koi herpesvirus DNA was detected in two of 15 grass carp that were exposed to the virus, in one grass carp sampled 14 days after the initial contact with the virus carrier, and in one which cohabited from the $14^{\text {th }}$ to $28^{\text {th }}$ day with five naive carp. In one of these carp CyHV-3 DNA was detected. Other common carp and grass carp did not show any symptoms of disease and they were CyHV-3 PCR negative.

\section{DISCUSSION}

The worldwide distribution of $\mathrm{KHV}$ within a few years of the first isolation (Bretzinger et al., 1999; Hedrick et al., 2000; Neukirch and Kunz 2001; Way et al., 2001; Perelberg et al., 2003; Sano et al., 2004; Tu et al., 2004) suggests that this virus may have an undetectable latent phase and, through the unregulated live fish trade, this may have contributed to its international spread.

It is known that many of herpesvirus infections of animals and fish can establish a latent infection (Fraser et al., 1981; Rock and Fraser 1983; van Nieuwstadt et al., 2001). The viral genome is integrated into the genome of specific host cells. These hidden infections can be activated by the action of stress or immunosuppression (Roizmann, 1996), which leads to the reactivation 
of the virus. With improving diagnostic methods, evidence of the presence of KHV DNA in carp and koi carp without clinical symptoms were obtained (Gilad et al., 2004). Furthermore, Gilad et al., in 2004 showed that the detection of viral DNA is insufficient to establish whether a latent or persistent infection is present. Whether these fish can transmit virus upon contact with naïve fish or whether the virus can reactivate following some stressors proof is needed that these fish are true carriers. St-Hilaire et al., (2005) have provided the first evidence supporting this hypothesis when they detect reactivation of CyHV-3 in carp, several months after initial exposure.

In our study we confirmed that KHV may cause latent infections in KHVinfected fish and also that the koi herpesvirus transmission and epidemiology is more complex than it is thought before. We showed the potential of grass carp, prussian carp, goldfish and silver carp to interact with the virus, suggesting their importance in CyHV-3 transmission in nature. Furthermore, our in vivo study has demostrated a strong potential of these species to serve as vector species for CyHV-3, without showing any apparent clinical signs for several weeks of the experiment. These findings contribute to better understanding of CyHV-3 infection in nature, indicating its interaction not just with its traditional hosts, but also with other carp species.

\section{ACKNOWLEDGEMENT:}

This work was supported by the Ministry of Education, Science and Technological Development of the Republic of Serbia, TR31075, TR-31011.

Adress for correspondence:

Vladimir Radosavljević

Department of Fish Diseases

The Institute of Veterinary Medicine of Serbia

University of Belgrade

Vojvode Toze 14

11000 Belgrade

Serbia

E-mail: vladimiradosavljevic@gmail.com

\section{REFERENCES}

1. Bretzinger A, Fischer-Scherl T, Oumouna M, Hoffman R, Truyen U, 1999, Mass mortalities in koi, Cyprinus carpio, associated with gill and skin disease, Bulletin of European Association Fish Pathologists 19,182-5.

2. Chien T, Ming Chia W, Jong-Rong S, Shih-Yuh L, 2004, Detection of koi herpesvirus in Cyprinus carpio in Taiwan, Jpn Soc Fish Pathol, 39, 109-10.

3. Fraser W, Lawrance WC, Wroblewska Z, Gilden D, Koprowski H, 1981, Herpes simplex type 1 in human brain tissue, Proc Natl Acad Sci USA, 78, 6461-5.

4. Gilad O, Yun S, Adkinson MA, Way K, Willits NH, Bercovier $H$ et al., 2003, Molecular comparison of isolates of an emerging fish pathogen, koi herpesvirus, and the effect of water temperature on mortality of experimentally infected koi, $J$ Gen Virol, 84, 2661- 8.

5. Gilad O, Yun S, Zagmutt-Vergara FJ, Leutenegger CM, Bercovier H, Hedrick R, 2004, Concentrations of a koi herpesvirus (KHV) in tissues of experimentally infected Cyprinus carpio koi as assessed by real-time TaqMan PCR, Dis Aqua Organ, 60, 179-87. 
6. Grimmett SG, Warg JV, Getchell RG, Johnson DJ, Bowser PR, 2006, An unusual koi herpesvirus associated with a mortality event of common carp Cyprinus carpio in New York State, USA, J Wildlife Dis, 42, 658-62.

7. Haramoto E, Kitajima M, Katayama H, Ohgaki S, 2007, Detection of koi herpesvirus DNA in river water in Japan, J Fish Dis, 30, 59-61.

8. Hedrick RP, Gilad O, Yun S, Spangenberg J, Marty G, Nordhausen R et al., 2000, A herpesvirus associated with mass mortality of juvenile and adult koi, a strain of common carp, J Aqua Anim Health, 12, 44-57.

9. Hedrick RP, Waltzek TB, McDowell TS, 2006, Susceptibility of Koi Carp, Common Carp, Goldfish, and Goldfish x Common Carp Hybrids to Cyprinid Herpesvirus-2 and Herpersvirus-3, J Aqua Anim Health, 18, 26-34.

10. Ishioka T, Yoshizumi M, Izumi S, Suzuki K, Suzuki H, Kozawa K et al., 2005, Detection and sequence analysis of DNA polymerase and major envelope protein genes in koi herpesviruses derived from Cyprinus carpio in Gunma prefecture, Japan, Vet Microbiol, 110, 27-33.

11. Kucuktas H, Brady YL, 1999, Molecular biology of channel catfish virus, Aquaculture, 172, 147-61.

12. Neukirch M, Bottcher K, Bunnajirakul S, 1999, Isolation of a virus from koi with altered gills, Bull Europ Ass Fish Patholog, 19, 221-4.

13. Tu C, Weng MC, Shiau JR, Lin SY, 2004, Detection of Koi Herpesvirus in koi Cyprinus carpio in Taiwan, Fish Pathol, 39,109-10

14. Neukirch $M$, Kunz $U, 2001$, Isolation and preliminary characterization of several viruses from koi (Cyprinus carpio) suffering gill necrosis and mortality, Bulletin of the European Association of Fish Pathol, 21, 125-35.

15. Perelberg A, Smirnov M, Hutoran M, Diamant A, Bejerano Y, Kotler M, 2003, Epidemiological description of an new viral disease afflicting cultured Cyprinus carpio in Israel. Israeli $J$ Aquacult, Bamidgeh, 55, 5-12

16. Rock DL, Fraser NW, 1983, Detection of HSV-1 genome in central nervous system of latently infected mice, Nature, 302, 523-5.

17. Roizmann B, 1996, Herpesviridae, In: Field BF, Knipe DM, Howley PM, Field virology, 2. edition Lippincott-Raven, Philadelphia, 2221-30

18. Ronen A, Perelberg A, Abramowitz J, Hutoran M, Tinman S, Bejerano I et al., 2003, Efficient vaccine against the virus causing a lethal disease in cultured Cyprinus carpio, Vaccine, 21, 4677-84.

19. Sano M, Ito T, Kurita J, Yanai T, Watanabe N, Miwa S, lida T, 2004, First detection of koi herpesvirus in cultured common carp Cyprinus carpio in Japan, Fish Pathol, 39,165-7.

20. Shapira Y, Magen Y, Zak T, Kotler M, Hulata G, Levavi-Sivan B, 2005, Differential resistance to koi herpes virus (KHV)/carp nephritis and gill necrosis virus (CNGV) among common carp (Cyprinus carpio) strains and crossbreds, Aquaculture, 245, 1-11.

21. St-Hilaire S, Beevers N, Way K, Le Deuff M, Martin P, Joiner C, 2005, Reactivation of koi herpesvirus infections in common carp Cyprinus carpio, Dis Aqua Organ, 67, 15-23.

22. Van Nieuwstadt, AP, Dijkstra SG, Haenen OLM, 2001, Persistence of herpesvirus of eel Herpesvirus anguillae in farmed european eel Anguilla anguilla, Dis Aqua Organ, 45, 103-7.

23. Way K, Le Deuff M, Stone DM, Denham KL, St-Hilaire S, 2004, Diagnostics and research at CEFAS Weymouth laboratory 2000-2003, Report of International Workshop on Koi Herpesvirus, 12-13 February 2004, London. 
Acta Veterinaria (Beograd), Vol. 62, No. 5-6, 675-681, 2012.

\title{
NAJČEŠĆE VRSTE RIBA U POLIKULTURI SA ŠARANOM KAO NOSIOCI HERPES VIRUSA-3 CIPRINIDA
}

\author{
RADOSAVLJEVIĆ V, JEREMIĆ SVETLANA, ĆIRKOVIĆ M, LAKO B, MILIĆEVIĆ VESNA, \\ POTKONJAK A i NIKOLIN V
}

\section{SADRŽAJ}

U eksperimentalnom istraživanju smo želeli da utvrdimo da li ciprinidni herpes virus 3 (CyHV-3) može izazvati infekciju kod vrsta riba koje, prema raspoloživim podacima, nisu prijemčive za ovaj virus. U cilju utvrđivanja da li ove vrste riba, mogu doprineti širenju virusa, linjak, tolstolobik, amur, zlatni i srebrni karaš, su eksponirani CyHV-3 putem kohabitacije sa inficiranim šaranom bez kliničkih simptoma. Nakon toga, su kohabitirale sa zdravim šaranima tokom naredne dve nedelje, nakon čega je vršeno ispitivanje prisustva CyHV-3 pomoću PCR. Utvrđeno je prisustvo CyHV-3 u organima svih ispitivanih vrsta riba, kao i u organima šarana nakon dvonedeljne kohabitacije sa njima. U našem istraživanju je potvrđeno da CyHV-3 može izazvati latentnu infekciju kod inficiranih riba, kao i da CyHV-3 ima više domaćina nego što se ranije mislilo. Naše istraživanje doprinosi boljem razumevanju prenošenja CyHV-3 i ukazuje na značaj drugih vrsta riba koje se najčešće gaje u polikulturi sa šaranom u epizootiologiji CyHV-3. 
